ANADOLU, J. of AARI

ISSN: $1300-0225$ (Print)

E-ISSN: 2667-6087 (Online)

2020, 30 (2): 251-265

DOI: $10.18615 /$ anadolu. 835019

\title{
Bazı İspir Kuru Fasulye (Phaseolus vulgaris L.) Hatlarının Seleksiyonu Üzerine Bir Ön Çalışma
}

\author{
Cemil AYGOĞAN ${ }^{1}$ (D) Erdal ELKOCA ${ }^{2 *}$ (D) Kamil HALILOĞLU ${ }^{3}$ (D) $\quad$ Murat AYDIN $^{4}$ \\ 1,3 Atatürk Üniversitesi, Ziraat Fakültesi Tarla Bitkileri Bölümü, Erzurum/TURKEY \\ ${ }^{2}$ Ăgrı İbrahim Çeçen Üniversitesi, Meslek Yüksek Okulu Bitkisel ve Hayvansal Üretim Bölümü, \\ A ğr $/$ TURKEY
}

${ }^{4}$ Atatürk Üniversitesi, Ziraat Fakültesi Tarımsal Biyoteknoloji Bölümü, Erzurum/TURKEY

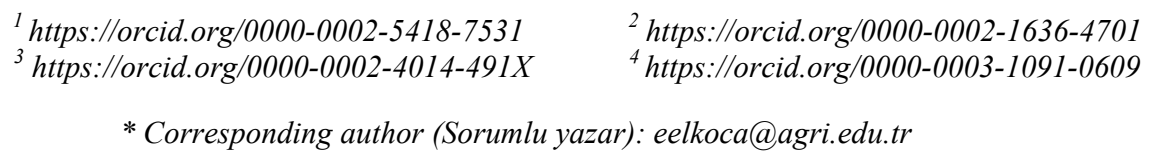

Received (Geliş tarihi): 12.06.2020Ａccepted (Kabul tarihi): 06.08.2020

\begin{abstract}
ÖZ: Erzurum'un Ispir ilçesinde yetişstiriciliği yapılan beyaz şeker tane tipindeki kuru fasulye populasyonu lezzetli oluşu ile tanınmakta ve ülke genelinde oldukça ilgi görmektedir. İspir fasulye populasyonundan elde edilen 40 İspir fasulye hattı bir önceki yıl karakterizasyon, seleksiyon ve ön verim denemelerine alınmış ve ümitvar bulunan 15 hat bu çalışmanın materyalini oluşturmuștur. Ümitvar bulunan hatlar bu çalışmada ise verim ve verim unsurları ile hastalıklara tolerans yönünden standart iki çeşitle (Elkoca-05 ve Aras-98) birlikte Erzurum'da 2015 yetiştirme sezonunda tesadüf bloklarl deneme deseninde 3 tekrarlamalı olarak denemeye alınmış ve bölge verim denemelerine aday olabilecek üstün hatların ortaya konulmasına çalışılmıştır. Araştırma sonuçları verim ve verim unsurları bakımından kuru fasulye hatları arasında önemli farklılıkların bulunduğunu göstermiştir. Hatlar aynı zamanda 14 adet kantitatif özellik bakımından kümeleme analizine tabi tutulmuş ve hatların iki ana grup altında kümelendiği belirlenmiştir. Birinci grup 10 İspir fasulye hattını içerirken, ikinci grupta standart çeşitlerle birlikte 5 İspir fasulye hattı (Kayıt no 6, 17, 32, 40 ve 69) kümelenmiştir. Gruplara ait ortalama değerler, ikinci gruptaki genotiplerin ortalama bir hafta erken olgunlaştığını, ayrıca bu gruptaki genotiplerin tane verimi ile birçok verim unsuru bakımından da daha üstün olduğunu ortaya koymuştur. Çalışma sonucunda, verim ve verim unsurlart ile hastalıklara dayanıklılık başta olmak üzere, incelenen özellikler bakımından üstünlük gösteren 6, 32, 40 ve 69 nolu İspir fasulye hatlarının bölge verim denemelerine aktarılmasına karar verilmiştir.
\end{abstract}

Anahtar kelimeler: İspir fasulyesi, Phaseolus vulgaris L., verim, verim unsurları, seleksiyon, korelasyon, kümeleme analizi.

\section{The Preliminary Study on Selection of some İspir Dry Bean (Phaseolus vulgaris L.) Lines}

ABSTRACT: Dry bean population with white circular seed types growing in the Ispir province of Erzurum is known by delicious taste and attracts considerable attention at nationwide. Forty bean lines obtained from Ispir bean population were taken for characterization, selection and pre-yield trials a year ago. Fifteen of the 40 lines were promising and constituted the material of this study. Promising lines were taken into experiments with two control varieties (Elkoca-05 and Aras-98) in terms of yield, yield components and resistance to diseases, in three randomized complete blocks in the growing season of 2015. The results showed that there were significant differences among the lines in terms of yield and yield components. The lines were subjected to cluster analysis in terms of 14 quantitative parameters and it was determined that the lines were clustered into two main groups. While the first group included 10 İspir bean lines, 5 İspir bean lines (Registration number: 6, 17, 32, 40 and 69) and standard varieties were clustered in the second group. The mean values of the groups revealed that the genotypes in the second group matured on average one week earlier, and that the genotypes in this group were superior in terms of grain yield and many yield components. As a result of the study, İspir bean lines 6, 32, 40 and 69, which show superiority in terms of yield, yield components and resistance to diseases, were decided to transfer to the regional yield experiments.

Keywords: İspir bean, Phaseolus vulgaris L., yield, yield components, selection, correlation, cluster analysis. 


\section{GíRiş}

Önemli bir yemeklik baklagil bitkisi olan fasulye (Phaseolus vulgaris L.), hem dünyada hem de ülkemizde yaygın olarak üretilip tüketilmektedir. Dünya'da kuru fasulye ekim alanı 34,5 milyon ha, üretim miktarı 30,4 milyon ton ve birim alan verimi $88,1 \mathrm{~kg} / \mathrm{da}$ olup, gerek ekim alanı ve gerekse üretim miktarı bakımından yemeklik tane baklagiller içerisinde ilk sırada yer almaktadır. Ülkemizde ise ekim alanı (84.786 ha), üretim miktarı (220.000 ton) ve dünya ortalamasından daha yüksek birim alan verimi $(259,5 \mathrm{~kg} / \mathrm{da})$ ile nohut ve mercimekten sonra en çok yetiştiriciliği yapılan yemeklik baklagildir (Anonim, 2018).

Ülkemize 1750'li yılların ortasında girdiği tahmin edilen fasulye, ülkemizin neredeyse her yerine iyi adapte olmuş ve geniş bir varyasyon göstermiştir. Ülkemizin hemen her bölgesinde kuru ve taze olarak yetiştirilen fasulye, ülke mutfağında önemli bir yer tutmakta ve halkımız tarafindan oldukça sevilerek tüketilmektedir. Kuru tanelerinde yüksek protein $(\% 18,0-31,6)$ içeriğine ilaveten, A, B1, B2 ve $\mathrm{D}$ vitaminleri, potasyum, magnezyum, demir, çinko ve lif açısından da oldukça zengin olan fasulye, insan beslenmesinde önemli bir role sahiptir (Pekşen ve Artık, 2005).

Ülkemizin bazı yörelerinde bitkisel üretim halen yerel çeşitler kullanılarak, aile ihtiyacı ya da yöresel pazarlara yönelik olarak yapılmaktadır. $\mathrm{Bu}$ yöreler lezzetli yerel materyalleri içeren ve değerlendirilmesi gereken çok önemli birer kaynak niteliğindedir. Kuru fasulye yetiştiriciliğinin yerel populasyonla yapıldı Erzurum'un İspir ilçesi, fasulye açısından böyle bir özellik taşımaktadır. Erzurum'un kuzey ilçesi olan İspir, Mescit dağlarının kuzey etekleri ile Çoruh nehri vadisinde yer alır. Rakımı ortalama $1050 \mathrm{~m}$, yüzölçümü ise $2100 \mathrm{~km}^{2}$ dir. İlçesinin doğusunda Tortum ve Yusufeli, batısında Pazaryolu, kuzeyinde Rize ve Artvin, güneyinde ise Bayburt ili bulunmaktadır. Ülkemizin önemli akarsularından olan Çoruh nehri ilçe sınırları içerisinden doğmaktadır. Çoruh nehri boyunca vadilerde bulunan küçük parsellerde bağ, bahçe ve fasulye yetiştiriciliği ön plana çıkmaktadır. Biyoçeşitlilik açısından oldukça zengin olan vadide, barajların tamamlanmasından sonra yaklaşı 103 bin ha tarım alanının su altında kalacağı ve çok sayıda endemik türün yanı sıra fasulye gen kaynaklarının da erozyona uğrayacağı öngörülmektedir (Sever, 2005).
İlçede yetiştiriciliği yapılan beyaz taneli şeker fasulyesi tipindeki populasyon, lezzetli ve iri taneli oluşu, yüksek oranda su alarak şişmesi, kabuk atmaması ve kısa sürede pişmesi nedeniyle "İspir fasulyesi" adı ile piyasada rağbet görmekte ve yüksek fiyattan alıcı bulmaktadır (Ozturk ve ark., 2009; Topcu ve ark., 2010; Sakiroglu ve ark., 2013). İspir fasulyesi yarı sarılıcı büyüme formundadır. Çiçek rengi çoğunlukla pembe, nadiren menekşe çok nadiren de beyazdır. Bakla zemin rengi yeşil olmakla birlikte, olgunluk ilerledikçe bakla üzerinde menekşe renginde yoğun ikinci renk oluşumu gözlenmektedir. Bakla kılçıklı, kesit şekli eliptik ve iç bükey olmak üzere orta seviyede kıvrıktır. Tane şekli dairesel-eliptik veya daireseldir. Ortalama 130-140 günde hasat olgunluğuna ulaşmaktadır (Bıyıklı, 2015).

İlçede yetiştiriciliği yapılan populasyonun saf olmayışı çeşitli sorunların yaşanmasına neden olmakta, bu nedenle daha verimli, kaliteli ve standart bir üretimin yapılabilmesi için ilçede yetiştirilen populasyon içerisinden populasyonu en iyi şekilde temsil edebilecek, üstün özelliklere sahip saf hatların belirlenmesine ihtiyaç duyulmaktadır. Diğer taraftan, fasulyede bakteriyel patojenlerin neden olduğu hale yanıklığı (Pseudomonas syringae pv. phaseolicola) serin ve nemli koşullarda, adi yaprak yanıklığı (Xanthomonas campestris pv. phaseoli) ise sıcak ve kurak koşullarda yaygın olarak görülmekte ve her iki bakteriyel hastalık da gerek Erzurum ve gerekse ülkemizin farklı bölgelerinde fasulye ekim alanlarında ciddi verim kayıplarına neden olabilmektedir (Kahveci ve Maden, 1994; Dönmez, 2004; Donmez ve ark., 2013). Fasulyede çok sayıda virüs hastalığ 1 da görülmekle birlikte en önemli zarar1 potyvirüsler yapmaktadır. Potyvirüsler içerisinde, hem afitlerle hem de tohumla yüksek oranda taşınmaları nedeniyle, en sı görülen ve ekonomik anlamda en önemli zarara neden olanlar ise fasulye adi mozaik virüsü (BCMV) ve fasulye adi nekroz mozaik virüsü (BCMNV)'dür (Mavric ve Sustar-Vozlic, 2004; Kılıç ve Yardımc1, 2020). Bu nedenle ilçede yetiştiriciliği yapılan fasulye populasyonu içerisinden hastalıklara toleranslı hatların seleksiyonu da büyük önem taşımaktadır.

İlçede yetiştiriciliği yapılan bu çok önemli yerel fasulye populasyonunun islahı ve seleksiyonu amacıyla şu ana kadar geniş kapsamlı bilimsel bir araştırmanın yürütülmemiş olması bu çalışmanın 
çıkış noktasını oluşturmuş ve bir seri çalıșma başlatılmıştır. Bu çalışmada, ilçede üretimi yapılan populasyon içerisinden seçilen ve ümitvar görülen bazı hatlar değerlendirilerek, tescil öncesi Bölge Verim Denemelerine aday olabilecek üstün hatların ortaya konulması amaçlanmıştır.

\section{MATERYAL ve METOT}

\section{Araştırmada kullanılan İspir fasulye hatları ve standart çeşitler}

İlçede kuru fasulye üretimi yapılan köylerden hasat döneminde toplanan 40 tek bitki (saf hat) karakterizasyon ve ön verim denemelerine alınarak değerlendirilmiş (Bıyıklı, 2015) ve çalışma sonunda, tane verimi ve olgunlaşma süresi başta olmak üzere, bazı özellikler bakımından ümitvar görülen 15 hat bu araştırmanın materyalini oluşturmuştur (Çizelge 1 ve 2).
Araștırmada, bașta Erzurum olmak üzere, Doğu Anadolu Bölgesi koşullarına uygunluğu yönüyle tescil ettirilmiş olan erkenci ve yüksek verimli iki kuru fasulye cessidi (Elkoca-05 ve Aras-98) ise standart olarak yer almıștır. Atatürk Üniversitesi Ziraat Fakültesi Tarla Bitkileri Bölümü tarafindan tescil ettirilen Elkoca-05, yarı sarılıcı büyüme formunda olup, çeşidin bitki başına ortalama bakla sayıs1 13 adet, bakladaki ortalama tane sayıs1 4 adet ve tane rengi beyazdır. Yüz tane ağırlığı ortalama 42,5 g olan çeşit, 110-130 günde hasat olgunluğuna ulaşmaktadır. Doğu Anadolu Tarımsal Araştırma Enstitüsü tarafindan tescil ettirilen Aras-98'de ise bitki başına bakla sayısı ortalama 17 adet, baklada tane sayisı ortalama 5 adet ve tane rengi beyazdir. Yüz tane ağırlı̆̆ ortalama 45,4 g olan çeşit, 110125 günde hasat olgunluğuna ulaşmaktadır.

Çizelge 1. Araştırmada kullanılan İspir fasulye hatları, temin edildikleri yer ve lokasyon bilgileri.

Table 1. İspir bean lines used in the study and their locations.

\begin{tabular}{llccc}
\hline \multirow{2}{*}{$\begin{array}{l}\text { Saf hat no. } \\
\text { Pure line nu. }\end{array}$} & $\begin{array}{l}\text { Toplandığı yer } \\
\text { Collection sites }\end{array}$ & \multicolumn{3}{c}{ Lokasyon (Location) } \\
\cline { 3 - 5 } & Öztoprak Köyü & $\begin{array}{c}\text { Enlem } \\
\text { Latitude }\end{array}$ & $\begin{array}{c}\text { Boylam } \\
\text { Longitude }\end{array}$ & $\begin{array}{c}\text { Rakım (m) } \\
\text { Altitude }\end{array}$ \\
\hline $3,4,6,10,16,17,19$ & Yeşilyurt Köyü & 40,518 & 41,052 & 1431 \\
$32,33,35$ & Maden Köyü & 40,518 & 41,069 & 1549 \\
39,40 & Elmalı Beldesi Ağ1ldere Köyü & 40,435 & 40,851 & 1226 \\
49 & Maden Köprübaş1 Beldesi Akbağ Mahallesi & 40,401 & 40,834 & 1470 \\
67,69 & & 40,434 & 40,819 & 1286 \\
\hline
\end{tabular}

Çizelge 2. Araştırmada kullanılan İspir fasulye hatlarının bazı özellikleri (Bıyıklı, 2015).

Table 2. Some features of İspir bean lines used in the study (B1yıkl1, 2015).

\begin{tabular}{|c|c|c|c|c|c|c|c|c|c|c|c|c|c|}
\hline Saf hat no. & $\mathrm{BS} \S$ & YR & YP & OYB & $\mathrm{BR}$ & BZR & BİR & TR & TŞ & EO & $\mathrm{BV}$ & TV & $\mathrm{HI}$ \\
\hline 3 & 1 & 2 & 2 & 1 & 2 & 1 & 1 & 1 & 1 & - & + & + & + \\
\hline 4 & 1 & 2 & 2 & 2 & 3 & 1 & 1 & 1 & 2 & + & + & + & + \\
\hline 6 & 1 & 1 & 1 & 1 & 2 & 1 & 1 & 1 & 2 & - & ++ & ++ & + \\
\hline 10 & 1 & 2 & 1 & 1 & 2 & 1 & 1 & 1 & 2 & ++ & + & + & + \\
\hline 16 & 1 & 2 & 2 & 1 & 2 & 1 & 1 & 1 & 2 & ++ & - & + & ++ \\
\hline 17 & 1 & 2 & 1 & 2 & 3 & 1 & 1 & 1 & 2 & ++ & + & + & + \\
\hline 19 & 1 & 2 & 2 & 2 & 3 & 1 & 1 & 1 & 2 & ++ & + & + & + \\
\hline 32 & 1 & 2 & 1 & 2 & 3 & 1 & 1 & 1 & 2 & - & ++ & + & + \\
\hline 33 & 1 & 1 & 1 & 1 & 2 & 1 & 1 & 1 & 2 & - & ++ & ++ & + \\
\hline 35 & 1 & 2 & 2 & 2 & 2 & 1 & 1 & 1 & 2 & + & + & + & + \\
\hline 39 & 1 & 2 & 2 & 2 & 2 & 1 & 1 & 1 & 1 & + & + & + & + \\
\hline 40 & 1 & 2 & 1 & 2 & 1 & 1 & 1 & 1 & 1 & ++ & + & ++ & ++ \\
\hline 49 & 1 & 2 & 1 & 2 & 2 & 1 & 1 & 1 & 2 & ++ & + & + & + \\
\hline 67 & 1 & 1 & 1 & 2 & 2 & 1 & 1 & 1 & 2 & - & + & + & + \\
\hline 69 & 1 & 3 & 1 & 1 & 2 & 1 & 1 & 1 & 2 & ++ & ++ & ++ & ++ \\
\hline
\end{tabular}

§ BS: büyüme șekli (growth type) 1: yarı sarılıcı (semi-climbing); YR: yaprak rengi (leaf colour) 1: açık yeșil (light green), 2: yeşil (green), 3: koyu yeşil (dark green); YP: yaprakta pürüzlülük (leaf roughness) 1: az pürüzlü (less rough), 2: orta pürüzlü (moderate rough); OYB: orta yaprakçık büyüklüğü (size of terminal leaflet) 1: orta (medium), 2: büyük (large); BR: bayrak rengi (standard colour) 1: beyaz (white), 2: pembe (pink), 3: menekşe (violet); BZR: bakla zemin rengi (pod ground colour) 1: yeşil (green); BİR: baklada ikinci renk (variegated colour in pod) 1: menekşe (violet); TR: tane rengi (seed colour) 1: beyaz (white); TŞ: tane şekli (seed shape) 1: dairesel-eliptik (circular-elliptical), 2: dairesel (circular); EO: erken olgunlaşma (early maturing); BV: biyolojik verim (biological yield); TV: tane verimi (seed yield); HI: hasat indeksi (harvest index). 


\section{Araştırma yerinin iklim özellikleri}

Araştırmanın yürütüldüğü 2015 yılının Mayıs, Haziran ve Eylül ayları uzun yıllar ortalaması civarında, Temmuz ayı uzun yıllar ortalamasından oldukça düşük, Ağustos ayı ise uzun yıllar ortalamasından oldukça yüksek yağış almıştır. Mayıs ve Eylül aylarını kapsayan 5 aylık gelişme mevsimi dikkate alındığında, araştırmanın yürütüldüğü 2015 yılının uzun yıllar ortalamasından daha yağışlı ve sıcak geçtiği, ortalama nispi nemin ise daha düşük olduğu görülmektedir (Çizelge 3).

\section{Araştırma yerinin toprak özellikleri}

Deneme arazisi killi-tınlı yapıda, hafif alkali $(\mathrm{pH}$ $7,26)$, tuz içeriği oldukça düşük $(0,12 \mathrm{mmhos} / \mathrm{cm})$ ve organik madde içeriği azdır $(\% 1,75)$. Az kireçli $(\% 0,38)$ olan deneme arazisi, az miktarda azot $(2,6$ $\mathrm{kg} / \mathrm{da})$, orta seviyede fosfor $(5,9 \mathrm{~kg} / \mathrm{da})$ ve yüksek miktarda potasyum $(106,9 \mathrm{~kg} / \mathrm{da})$ içermektedir (Aydın ve Sezen, 1995).

\section{Tarla çalışmaları}

Denemede kullanılan 15 adet saf hat, bölge için tescil ettirilmiş Elkoca-05 ve Aras-98 çeşitleri ile birlikte tesadüf blokları deneme deseninde 3 tekrarlamalı olarak Atatürk Üniversitesi Ziraat Fakültesi'nin Erzurum Merkezindeki deneme alanında seleksiyon ve ön verim denemelerine alınmışlardır. Denemede yer alan genotipler bloklarda bulunan parsellere şansa bağlı olarak dağıtılmıştır. Her parselde sıra aras $50 \mathrm{~cm}$ ve uzunluğu $4 \mathrm{~m}$ olan 4 bitki sırası yer almıştır. Ekim, 18 Mayıs 2015 'te elle 5-6 cm derinliğe yapılmıştır. Ekimde sira üzeri 6-7 cm olacak şekilde ayarlanmış ve böylece her parselde metrekareye yaklaşı 32 adet tohum ekilmiştir. Ekimden hemen önce parsellere $4 \mathrm{~kg} / \mathrm{da} \mathrm{N}$ ve $6 \mathrm{~kg} / \mathrm{da} \mathrm{P}_{2} \mathrm{O}_{5}$ hesabiyla $\% 21$ 'lik amonyum sülfat ve $\% 45^{\prime}$ lik triple süperfosfat gübreleri uygulanmış ve toprağa karıştırılmıştır (Anonim, 2001). Biri çiçeklenme öncesi, üçü bakla bağlama ve tane dolum dönemlerinde olmak üzere, deneme alanı ihtiyaç duyuldukça salma yöntemi ile sulanmıştır. Yabancı otlar gerek duyuldukça çapa ile kontrol altına alınmıştır. Hasat olgunluğu döneminde bitkiler elle yolunmuş ve her parsel ayrı ayrı çuvallara alınarak seraya taşınmıştır. Serada 3-4 günlük kuruma sürecinden sonra harman işlemi gerçekleştirilmiştir.

\section{Verilerin elde edilişi}

Denemede, Tohumluk Tescil ve Sertifikasyon Merkezi Müdürlüğü'nün Tarımsal Değerleri Ölçme Denemeleri Teknik Talimatında (Anonim, 2001) belirttiği gözlem ve ölçümler yapılmıştır. Çalışmada ayrıca bakteri ve virüs hastalık gözlem ve tanımları da yapılarak, hatların hastalık durumları $1-5$ skalasina $(1=$ toleransl1, $2=$ orta toleransl1, $3=$ orta hassas, $4=$ hassas, $5=$ çok hassas) göre değerlendirilmiştir (Donmez ve ark., 2013; Boersma ve ark., 2014).

\section{Verilerin değerlendirilmesi}

Verilere ait varyans analizleri MSTATC paket programı kullanılarak yapılmıştır (Freed ve ark., 1985). Ortalamalar arasindaki farklar ise Duncan çoklu karşılaştırma testi ile \%5 ihtimal seviyesinde kontrol edilmiştir (Yıldız ve Bircan, 1991). Korelasyon, aşamalı (stepwise) çoklu regresyon ve cluster (kümeleme) analizleri için SPSS paket programı kullanılmıştır (Anonymous,, 2011). Kümeleme analizinde Ward's yöntemi esas alınmıştır (Ward, 1963).

Çizelge 3. Erzurum ovasının araştırmanın yürütüldüğü ürün yılı ile uzun yıllar ortalamasına (1990-2015) ait bazı iklim verileri (Anonim, 2015).

Table 3. Some climate data of research year and long-term average (1990-2015) in Erzurum plain (Anonim, 2015).

\begin{tabular}{|c|c|c|c|c|c|c|c|c|}
\hline \multirow{2}{*}{$\begin{array}{l}\text { İklim özellikleri } \\
\text { Climatic properties }\end{array}$} & & \multicolumn{5}{|c|}{$\begin{array}{l}\text { Aylar } \\
\text { Months }\end{array}$} & \multicolumn{2}{|c|}{$\begin{array}{c}\text { Toplam/Ortalama } \\
\text { Total/Average }\end{array}$} \\
\hline & & $\begin{array}{l}\text { Mayıs } \\
\text { May }\end{array}$ & $\begin{array}{l}\text { Haziran } \\
\text { June }\end{array}$ & $\begin{array}{l}\text { Temmuz } \\
\text { July }\end{array}$ & $\begin{array}{l}\text { Ağustos } \\
\text { August }\end{array}$ & $\begin{array}{l}\text { Eylül } \\
\text { Sept. }\end{array}$ & $\begin{array}{r}\text { Gelişme mevsimi } \\
\text { Growing season }\end{array}$ & $\begin{array}{c}\text { Yillık } \\
\text { Annual }\end{array}$ \\
\hline Toplam yağış (mm) & 2015 & 69,8 & 73,3 & 13,6 & 56,0 & 10,8 & 223,5 & 602,9 \\
\hline Total rainfall $(\mathrm{mm})$ & UYO $\S$ & 57,8 & 66,2 & 40,4 & 23,9 & 13,9 & 202,5 & 388,0 \\
\hline Ortalama hava sıcaklığı $\left({ }^{\circ} \mathrm{C}\right)$ & 2015 & 10,1 & 15,7 & 20,0 & 20,5 & 17,2 & 16,7 & 6,0 \\
\hline Average air temperature $\left({ }^{\circ} \mathrm{C}\right)$ & UYO $\S$ & 10,5 & 14,8 & 19,2 & 19,4 & 14,0 & 15,6 & 5,1 \\
\hline Ortalama nispi nem (\%) & 2015 & 66,6 & 58,7 & 46,4 & 45,4 & 43,5 & 52,1 & 66,8 \\
\hline Average relative humidity (\%) & UYO $\S$ & 64,1 & 59,9 & 53,3 & 49,7 & 52,5 & 55,9 & 66,5 \\
\hline
\end{tabular}




\section{BULGULAR ve TARTIŞMA}

\section{Genotiplerin fenolojik özellikleri}

Fasulyede çimlenme için gerekli toplam sıcaklık isteği yönünden genotipler arasında varyasyon görülebilmekte ve toplam sıcaklık isteği düşük olan genotipler kısa sürede çimlenip çıkış yapmaktadırlar (Wagenvoort ve Bierhuizen, 1977; Kantar ve Elkoca, 2001). Bu araştırmada da varyans analizi sonuçları genotipik etkinin çıkış süresi bakımından önemli olduğunu göstermiştir (Çizelge 4). Aras-98, çalışmada yer alan diğer bütün genotiplerden önemli seviyede daha erken (12,0 gün) çıkış yaparken, İspir fasulye hatlarında çıkış süresi 13,3-14,0 gün olmak üzere oldukça dar bir aralıkta değişim göstermiştir (Çizelge 4). İspir fasulye hatlarının tamamı bölge koşulları için tescil ettirilmiş olan Elkoca-05 ile benzer sürede çıkış yapmışladır.

Çimlenmede olduğu gibi, çiçeklenme ve olgunlaşma için gerekli toplam sıcaklık gereksinimi yönünden de genotipler arasında önemli farklar görülebilmekte ve toplam sıcaklık gereksinimi düşük olan genotipler daha kısa sürede çiçeklenip olgunlaşmaktadırlar (Ustaoğlu, 2008). Varyans analizi sonuçları, bu çalışmada da çiçeklenme ve olgunlaşma süresinin genotiplere bağlı olarak önemli değişim gösterdiğini ortaya koymuştur (Çizelge 4). Çiçeklenme süresi genotiplere bağlı olarak 42,0 gün ile 52,3 gün arasında değişim göstermiş; en erken ve en geç çiçeklenen genotipler arasında yaklaşık 10 günlük bir farkın olduğu saptanmıştır. En uzun çiçeklenme süresi (52,3 gün) Elkoca-05 çeşidinde saptanırken, İspir fasulye hatlarının tamam1, önemli seviyede olmak üzere, Elkoca-05 çeşidinden daha kısa sürede çiçeklenmiştir (Çizelge 4). Diğer taraftan, 3, 6, 10, 19 ve 49 nolu hatlar Aras-98 ile benzer çiçeklenme süresine sahip olurken, istatistiki olarak aynı grup içerisinde yer almakla birlikte beş hat (kaylt no 4, 16, 17, 39 ve 67) Aras-98'den 1-2 gün daha erken çiçeklenmiştir (Çizelge 4).

En kısa olgunlaşma süresi (114,3 gün) Aras-98 çeşidinde tespit edilmiştir. Olgunlaşma süresi İspir fasulye hatlarında ise 132,3 gün ile 140,0 gün arasında önemi bir değişim göstermiş ve hatların tamamı Aras-98'den daha geç hasat olgunluğuna ulaşmıştır (Çizelge 4). Elkoca-05 ise ekimden 134,0 gün sonra oluma ulaşmış ve olgunlaşma süresi 132,3 gün ile 138,0 gün arasında değişim gösteren 10 hat (kayıt no 4, 6, 17, 32, 35, 39, 40, 49, 67 ve 69) Elkoca-05 ile benzer olgunlaşma süresine sahip oluşuyla dikkati çekmiştir. Genotipik etkiye bağlı olarak çiçeklenme ve olgunlaşma süresi bakımından fasulye genotipleri arasında önemli farkların bulunduğu yapılan diğer birçok çalışma sonucunda da ortaya konulmuştur (Bozoğlu ve Sözen, 2007; Güneş, 2011; Bıyıklı, 2015).

\section{Metrekaredeki bitki sayısı}

Metrekarede çıkış yapan bitki sayısı 26,8 adet (kayit no 10) ile 31,2 adet (Elkoca-05) arasında olmak üzere genotiplere bağlı olarak önemsiz bir değişim göstermiştir (Çizelge 4). Tohumluk Tescil ve Sertifikasyon Merkezi Müdürlüğü'nün yayınlamış olduğu Tarımsal Değerleri Ölçme Denemeleri Teknik Talimatına göre (Anonim, 2001), kuru fasulyede bitki sıklı̆̆ının 27-28 adet $/ \mathrm{m}^{2}$ olması gerekmektedir. Teknik talimatla kıyaslandığında, araştırmamızda yer alan çeşit ve hatların tamamında bitki sıklığının ideale yakın olduğu anlaşılmaktadır.

\section{Bitki boyu}

Varyans analizi sonuçları bitki boyu bakımından genotipik etkinin önemli olduğunu göstermiştir. En kısa bitki boyu $53,3 \mathrm{~cm}$ ile bodur gelişme karakterinde olan Aras-98 çeşidinde ölçülmüsşür. Yarı sarılıcı karakterde olan Elkoca-05 çeşidinde $77,5 \mathrm{~cm}$ olan bitki boyu, yine yarı sarılic1 karakterde olan İspir fasulye hatlarında ise $67,5 \mathrm{~cm}$ ile $110,5 \mathrm{~cm}$ arasında olmak üzere çok önemli bir değişim göstermiştir. Bitki boyu $67,5 \mathrm{~cm}$ ile 88,2 $\mathrm{cm}$ arasında değişim gösteren 9 hat Elkoca-05 ile aynı grup içerisinde yer almıştır. Bitki boyu 95,7 $\mathrm{cm}$ ile 110,5 $\mathrm{cm}$ arasında değişen 6 hat ise (kayit no 3, 6, 32, 33, 40 ve 69) Elkoca-05'ten önemli seviyede yüksek bitki boyu değerlerine sahip olmuştur (Çizelge 4). Fasulyede bitki boyunun yüksek bir kalıtım derecesine sahip olduğu belirtilmektedir (Çiftçi ve Şehirali, 1984). Bu nedenle farklı ekolojik koşullar altında yürütülen diğer çalışmalarda da genotipik etkinin bir sonucu olarak, fasulyede bitki boyu bakımından önemli varyasyonların bulunduğu rapor edilmektedir (Bozoğlu ve Sözen, 2007; Bıyıklı, 2015). 


\section{İlk bakla yüksekliği}

İlk bakla yüksekliği makinalı hasada uygunluğun önemli bir göstergesi olup baklaları yüksekte teşekkül eden çeşitler makinayla hasat edilebilmektedir. İlk bakla yüksekliği standart çeşitlerde 12,3 cm (Elkoca-05) ve 14,1 cm (Aras98) olarak ölçülmüştür. İspir fasulye hatlarında ise $12,1 \mathrm{~cm}$ (kayit no 39) ile 17,6 cm (kayit no $32 \mathrm{ve}$ 40) arasında değişim göstermiş ve 32 ile 40 nolu hatlar her iki standart çeşitten önemli seviyede yüksek ilk bakla yüksekliği ile oldukça dikkat çekici bulunmuşlardır. İlk bakla yüksekliğinin $15,0-15,7 \mathrm{~cm}$ arasında değişim gösterdiği 4 hat (kayit no 4, 6, 33 ve 69) ise genel ortalamadan $(14,2 \mathrm{~cm})$ yüksek ilk bakla yüksekliği değerleri ile ön plana çıkmışlardır (Çizelge 4). Diğer çalışmalarda da ilk bakla yüksekliği bakımından fasulye genotipleri arasında önemli farkların bulunduğu saptanmıştır (Anlarsal ve ark., 2000; Düzdemir ve Akdağ, 2001; Özbekmez, 2015).

\section{Bitki başına dal sayısı}

Varyans analizi sonuçları dal sayısı üzerine genotiplerin önemli $(\mathrm{P}<0,05)$ etkide bulunduğunu göstermiştir (Çizelge 4). Kontrol çeşitlerinde bitki başına 4,13 adet (Elkoca-05) ve 4,80 adet (Aras98) olan dal sayısı İspir fasulye hatlarında 2,874,57 adet arasında önemli bir varyasyon göstermiştir. İspir fasulye hatları içerisinde en yüksek dal sayısı 4,57 adet ile 69 nolu hatta tespit edilmiş ve bu hat Aras-98 ile istatistiki olarak aynı grup içerisinde yer almıştır. Bitki başına dal sayısı 3,40 adet ile 4,07 adet arasında değişen 10 İspir fasulye hattı ise Elkoca-05 çeşidi ile istatistiki anlamda benzer dal sayısına sahip olmuştur (Çizelge 4). Bitki başına dal sayısı bakımından fasulye genotipleri arasında önemli farkların bulunduğu diğer araştırıcılar tarafından da belirlenmiştir (Özçelik ve Gülümser, 1988; Pekşen ve Gülümser, 2005; Dumlu, 2009; Varankaya, 2011; Bıyıklı, 2015).

\section{Bitkide bakla sayısı}

Varyans analizi sonuçları bitkide bakla sayısı bakımından genotipik etkinin önemli $(p<0,05)$ olduğunu göstermiştir (Çizelge 4). Standart çeşitlerde bitki başına bakla sayısı 9,4 (Elkoca-05) ve 10,2 adet (Aras-98) iken, İspir fasulye hatlarında 8,4 adet (kayit no 35) ile 18,4 adet (kayit no 69) arasında önemli bir değişim göstermiştir. Bakla sayısı bakımından 69 nolu hat ön plana çıkmış ve bu hattın bakla sayısı standart çeşitlerden önemli seviyede yüksek bulunmuştur. Geri kalan hatlar ise standart çeşitlerle aynı grubu paylaşmakla birlikte, beş tanesi (kayıt no 6, 32, 33, 39 ve 49) genel ortalamanın (11,7 adet) üstünde yer almıştır. (Çizelge 4). Yapılan diğer pek çok çalışmada da bitki başına bakla sayısının genotipler arasında önemli varyasyon gösterdiği belirlenmiştir (Anlarsal ve ark., 2000; Elkoca ve Kantar, 2004; Varankaya, 2011; B1y1kl1, 2015).

\section{Bakla uzunluğu}

Varyans analizi sonuçları incelendiğine, bakla uzunluğu üzerine genotiplerin önemli etkide bulunduğu anlaşılmaktadır (Çizelge 4). Elkoca-05, çalışmada yer alan bütün genotiplerden önemli seviyede yüksek bakla uzunluğuna $(15,0 \mathrm{~cm})$ sahip olmuştur. Bakla uzunluğu $11,4 \mathrm{~cm}$ ile $12,7 \mathrm{~cm}$ arasında yer alan beş İspir fasulye hattı (kayıt no 3, 6, 32, 33 ve 40), Aras-98 (12,4 cm) ile aynı grup içerisinde yer almıştır (Çizelge 4). Diğer İspir fasulye hatlarında ise bakla uzunluğu $8,6 \mathrm{~cm}$ (kayıt no 16) ile 10,4 cm (kayıt no 69) arasında değişim göstermiş ve bu hatlar bakla uzunluğu bakımından tescilli çeşitlerin gerisinde kalmıştır. Benzer şekilde, fasulyede bakla uzunluğunun 9,4-12,5 cm (Elkoca ve Kantar, 2004), 4-22 cm (Sözen, 2006) ve 7,3-11,8 cm (Dumlu, 2009) arasinda olmak üzere, genotiplere bağlı olarak önemli değişim gösterdiği diğer araştırmalar sonunda da rapor edilmiştir.

\section{Baklada tane sayısı}

Varyans analizi sonuçları baklada tane sayısı üzerine genotiplerin çok önemli $(\mathrm{P}<0,01)$ etkide bulunduğunu göstermiştir (Çizelge 4). Elkoca-05 ve Aras-98 çeşitlerinde bakladaki tane sayıs1 sırasıyla 4,47 ve 4,20 adet olarak gerçekleşmiştir. İspir fasulye hatlarında ise bakladaki tane sayıs1 3,27-6,13 adet arasında olmak üzere geniş bir aralıkta değişim göstermiştir. En yüksek baklada tane sayıs 40 ve 32 nolu hatlarda tespit edilmiş (sirasiyla 6,13 ve 5,13 adet) ve bu hatlar, önemli seviyede olmak üzere, diğer bütün çeşit ve 
hatlardan daha yüksek baklada tane sayıları ile oldukça dikkat çekici bulunmuşlardır (Çizelge 4). Diğer taraftan 3,33 ve 6 nolu hatların bakladaki tane sayıs1 (sirasiyla 4,93, 4,73 ve 4,47 adet) genel ortalamadan $(4,16$ adet) daha yüksek olmuştur. Diğer hatlarda ise bakladaki tane sayısı 3,27-4,13 adet arasında değişim göstermiş ve genel ortalamanın gerisinde yer almışlardır. Erzurum (Elkoca ve Kantar, 2004), Van-Gevaş (Güneş, 2011), Yozgat (Varankaya, 2011) ve Ordu ekolojik koşullarında (Özbekmez, 2015) yürütülen diğer çalışmalarda da bakladaki tane sayısının ekolojik koşullara ve genotiplere bağlı olarak 2,35 adet ile 9,60 adet arasında olmak üzere geniş bir aralıkta değişim gösterdiği saptanmıştır.

\section{Yüz tane ağırlığı}

Araştırmada kullanılan genotiplerin yüz tane ağırlıkları 42,2 g ile 60,3 g arasında yer almış ve yüz tane ağırlığ bakımından genotipik etkinin çok önemli $(\mathrm{P}<0,01)$ olduğu anlaşılmıştır (Çizelge 4). En düşük yüz tane ağırlığına (42,2 g) Aras-98 çeşidi sahip olmuş ve İspir fasulye hatlarının tamamında yüz tane ağırlığı Aras-98'den önemli seviyede yüksek bulunmuştur. Elkoca-05'te ise yüz tane ağ ağırlığ $59,5 \mathrm{~g}$ ile 60,3 g arasında değişen dört İspir fasulye hattı (kayıt no 4, 16, 17 ve 67) Elkoca05 'ten önemli seviyede yükssek yüz tane ağırlığı ile dikkat çekici bulunmuşlardır (Çizelge 4). Yüz tane ağırlığ $55,8 \mathrm{~g}$ ile 57,7 g arasında değişen beş İspir fasulye hattı ise Elkoca-05 ile ayn istatistiki gruba girmekle birlikte, hem Elkoca-05'ten hem de genel ortalamadan $(55,5 \mathrm{~g})$ daha yüksek değerlere sahip olmuşlardır. En düşük yüz tane ağırlığ 1 ise $52,2-$ 53,3 g arasında değişmek üzere 3, 39 ve 69 nolu hatlarda saptanmıştır (Çizelge 4). Benzer şekilde, Akdağ ve Şahin (1994) fasulyede yüz tane ağırlığının 23,4-62,8 g, Balkaya (1999) 22,2-125,3 $\mathrm{g}$ ve Varankaya (2011) ise 25,9-46,9 g arasinda olmak üzere, genotiplere bağlı olarak önemli değişim gösterdiğini saptamışlardır.

\section{Biyolojik verim}

Varyans analiz sonuçları, biyolojik verim üzerine genotip etkisinin çok önemli $(\mathrm{P}<0,01)$ olduğunu göstermiştir (Çizelge 4). Aras-98 ve Elkoca-05'te sirasiyla 656,4 ve $783,3 \mathrm{~kg} / \mathrm{da}$ olan biyolojik verim, İspir fasulye hatlarında $514,4 \mathrm{~kg} / \mathrm{da}$ ile $837,6 \mathrm{~kg} / \mathrm{da}$ arasında değişim göstermiştir. Biyolojik verimi $783,3 \mathrm{~kg} / \mathrm{da}$ ile $837,6 \mathrm{~kg} / \mathrm{da}$ arasinda yer alan 6,32 ve 69 nolu İspir fasulye hatları Elkoca-05 ile birlikte ilk grubu oluşturmuşlardır (Çizelge 4). Biyolojik verimi $681,7 \mathrm{~kg} / \mathrm{da}$ ile $729,7 \mathrm{~kg} / \mathrm{da}$ arasında değişen üç ispir fasulye hattı ise (kayıt no 3, 17 ve 40), istatistiki olarak Aras-98 ile aynı grup içerisinde yer almakla birlikte, hem Aras-98'den hem de genel ortalamadan daha yüksek biyolojik verim değerleri ile dikkati çekmişlerdir. Geriye kalan 9 İspir fasulye hatt1 ise hem genel ortalamanın $(672,6 \mathrm{~kg} / \mathrm{da})$ hem de standart çeşitlerin gerisinde yer almışlardır (Çizelge 4). Biyolojik verimin Samsun ekolojik koşullarında 407,0-694,6 kg/da (Bozoğlu, 1995), Konya ekolojik koşullarında 322,2-850,0 kg/da (Ceyhan ve ark., 2009) ve Van ekolojik koşullarında ise $531,8-891,9 \mathrm{~kg} / \mathrm{da}$ (Zirek, 2015) olmak üzere genotipler arasında önemli değişim gösterdiği diğer araştırma sonuçları ile de ortaya konulmuştur.

\section{Tane verimi}

Varyans analizi sonuçları tane verimi bakımından genotipik etkinin çok önemli $(\mathrm{P}<0,01)$ olduğunu ortaya koymuştur (Çizelge 4). Elkoca-05 çeşidinden $229,0 \mathrm{~kg} / \mathrm{da}$ ve Aras-98'den ise $276,7 \mathrm{~kg} / \mathrm{da}$ tane verimi elde edilirken, İspir fasulye hatlarının tane verimi $92,9 \mathrm{~kg} / \mathrm{da}$ ile $285,0 \mathrm{~kg} / \mathrm{da}$ arasında önemli bir değişim göstermiş̧ir (Çizelge 4). Tane verimi $185,2-270,2 \mathrm{~kg} / \mathrm{da}$ arasında değişen yedi hat (kayıt no $6,17,32,39,40,49$ ve 67) Elkoca-05 ile ayn grup içerisinde yer alırken, 69 nolu hat Elkoca05 'ten önemli seviyede yüksek tane verimi $(285,0$ $\mathrm{kg} / \mathrm{da}$ ) ile oldukça dikkat çekici bulunmuştur. Ayrıca, istatistiki olarak Elkoca-05 ile aynı grup içerisinde yer almakla beraber, tane verimi Elkoca05 'ten yüksek olan ve Aras-98 ile ayn 1 grup içerisinde yer alan $32(270,2 \mathrm{~kg} / \mathrm{da}), 40(268,8$ $\mathrm{kg} / \mathrm{da})$ ve $6(250,8 \mathrm{~kg} / \mathrm{da})$ nolu hatlar da oldukça ümitvar bulunmuştur. Tane verimi $92,9 \mathrm{~kg} / \mathrm{da}$ ile $171,7 \mathrm{~kg} / \mathrm{da}$ arasında değişen yedi ispir fasulye hatt1 (kayıt no 3, 4, 10, 16, 19, 33 ve 35) ise her iki çeşitten de önemli seviyede düşük tane verimi ile alt sıralarda yer almışlardır (Çizelge 4). Bulgularımıza paralel olarak, Van-Gevaş fasulye populasyonundan seçtiği 21 hat üzerinde çalışan Güneş (2011), populasyon içerisinde seleksiyona 
imkan sağlayacak önemli bir varyasyon bulunduğunu ve genotipik etkiye bağlı olarak hatların tane veriminin 145,6-512,1 kg/da olmak üzere oldukça önemli aralıkta değişim gösterdiğini saptamıştır. Diğer pek çok araştırıcı da fasulyede tane veriminin Samsun ekolojik koşullarında 162,7-237,7 kg/da (Bozoğlu, 1995), Tokat ekolojik koşullarında 73,4-205,9 kg/da (Düzdemir ve Akdağ, 2001), Konya ekolojik koşullarında 111,2$299,4 \mathrm{~kg} / \mathrm{da}$ (Ceyhan ve ark., 2009) ve Yozgat ekolojik koşullarında ise 150,4-400,7 kg/da arasında olmak üzere (Varankaya, 2011) genotiplere bağlı olarak önemli değişim gösterdiğini belirlemişlerdir.

\section{Hasat indeksi}

Varyans analizi sonuçları hasat indeksi bakımından genotipik etkinin çok önemli $(\mathrm{P}<0,01)$ olduğunu ortaya koymuştur. Aras-98 çeşidi \% 42,3 ile kullanılan genotipler arasında ilk sırada yer almıştır. Hasat indeksi değeri \%38,0 ve \%35,6 olarak gerçekleşen, sirasiyla 40 ve 69 nolu hatlar Aras-98 ile istatistiki olarak aynı grup içerisinde yer almışlardır (Çizelge 4). Hasat indeksi değerleri $\% 23,8$ ile $\% 32,0$ arasında değişim gösteren $4,6,17,19,32,33,35$, 39, 49 ve 67 nolu hatlar ise istatistiki anlamda Elkoca-05 $(\% 29,2)$ ile benzer bulunmuştur. Geriye kalan 3, 10 ve 16 nolu hatların hasat indeksi değerleri ise $(\% 18,2-21,4)$ hem standart çeşitlerden hem de 19 ve 33 nolu hatlar hariç, diğer bütün hatlardan önemli seviyede düşük olmuştur (Çizelge 4). Toplam kuru madde üretimi içindeki tane ürünün payını ifade eden hasat indeksinin fasulyede genotiplere bağlı olarak, Samsun ekolojik koşullarında \%26-39 (Özçelik ve Gülümser, 1988), Tokat ekolojik koşullarında \%23,9-46,0 (Düzdemir ve Akdağ, 2001) ve Konya ekolojik koşullarında ise \%21,2-40,1 arasinda (Ceyhan ve ark., 2009) önemli değişim gösterdiği diğer araştırma sonuçlarıyla da ortaya konulmuştur.

\section{Hastalık gözlemleri}

Yapılan gözlemlerde İspir fasulye hatlarının tamamında ve Elkoca-05 çeşidinde hiçbir bakteriyel hastalık belirtisine rastlanmamış ve bakteriyel hastalıklara toleranslı oldukları belirlenmiştir (Çizelge 5). Aras-98'de ise bakteriyel adi yaprak yanıklığ (Xanthomonas axonopodis pv. phaseoli) semptomları gözlenmiş (Donmez ve ark., 2013) ve Aras-98'in adi yaprak yanıklığına hassas olduğu tespit edilmiştir. Diğer taraftan, standart çeşitler ile 5 hatta (kayıt no 6, 32, 33, 40 ve 69) hiçbir virüs hastalığı belirtisine rastlanmamıştır. Diğer hatlarda ise fasulye adi mozaik virüsü semptomları gözlenmiş (Boersma ve ark., 2014) ve yapılan hastalık şiddeti değerlendirmelerinde $3,10,35$ ve 39 nolu hatlar orta hassas; 4 ve 16 nolu hatlar hassas; 17, 19, 49 ve 67 nolu hatlar ise çok hassas bulunmuştur (Çizelge 5).

\section{Verim ve Verim Unsurları Arasındaki İlișkiler}

Araştırmada ele alınan özellikler arasındaki doğrusal ilişkilere ait basit korelasyon katsayılarını gösteren Çizelge 6 incelendiğinde, bitkide bakla sayısı, baklada tane sayısı, ilk bakla yüksekliği ve biyolojik verimin bitki boyu ile pozitif yönde ve önemli ilişki içinde olduğu anlaşılmaktadır. Ayrıca, bitkide bakla sayısının dal sayısı ile $\left(\mathrm{r}=0,51^{*}\right)$, baklada tane sayısının ise bakla uzunluğu ve ilk bakla yüksekliği ile de ilişkisinin pozitif yönde ve önemli (sirasiyla $r=0,67^{* *}$ ve $r=0,55^{*}$ ) olduğu belirlenmiştir. Diğer taraftan, çiçeklenme süresindeki artışın bakla uzunluğu $\left(\mathrm{r}=0,76^{* *}\right)$ ve biyolojik verimi $(\mathrm{r}=0,50 *)$ önemli seviyede yükselttiği; olgunlaşma süresindeki gecikmenin ise gerek dal sayıs1 ve gerekse önemli verim unsurlarından biri olan hasat indeksini önemli seviyede azalttığ 1 (sırasiyla $\mathrm{r}=-0,70^{* *}$ ve $\mathrm{r}=-0,76^{* *}$ ) tespit edilmiştir. Biyolojik verimin ayrıca, bitki başına bakla sayısı $\left(\mathrm{r}=0,55^{*}\right)$, bakla uzunluğu $\left(\mathrm{r}=0,60^{*}\right)$, baklada tane say1s1 $\left(\mathrm{r}=0,50^{*}\right)$ ve bitkide dal say1s1 $\left(\mathrm{r}=0,50^{*}\right)$ ile pozitif yönde önemli ilişki içinde olduğu saptanmıştır. Hasat indeksinin dal sayısı ve biyolojik verim ile olan ilişkisinin ise pozitif yönde ve önemli (sırasıyla $r=0,60^{* *}$ ve $r=0,51^{*}$ ) olduğu anlaşılmıştır. Korelasyon katsayıları yüz tane ağırlığının dal sayısı ile negatif $\left(\mathrm{r}=-0,59^{*}\right)$, çıkış ve olgunlaşma süresi ile pozitif yönde önemli (sırasıyla $\mathrm{r}=0,70^{* *}$ ve $\mathrm{r}=0,76^{* *}$ ) ilişki içinde olduğunu göstermiştir. $\mathrm{Bu}$ sonuç, iri taneli genotiplerin daha geç çıkış yaptığını ve daha geç olgunlaştığını ifade etmektedir. İncelediğimiz özellikler arasındaki benzer ilişkilerin varlığına diğer araştırıcılar tarafından da işaret edilmiştir (Bozoğlu, 1995; Anlarsal ve ark., 2000; Pekşen ve 
Gülümser, 2005; Elkoca ve Çınar, 2015; Bıyıklı, 2015).

Erzurum ve benzer ekolojilerde fasulyenin soğuk ve don zararına uğramadan gelişebileceği dönem oldukça kısadır. Bu nedenle kısa sürede gelişerek, sonbahar ilk donlarından önce olgunlaşan çeşitlerin yetiştirilmesi/geliştirilmesi, bu tip bölgelerde fasulye tarımında ortaya çıkabilecek risklerin giderilmesi yönünden büyük önem taşımaktadır (Elkoca ve Kantar, 2004). Bu çalışmada hesapladığımız korelasyon katsayıları bu durumu doğrulamış ve olgunlaşma süresindeki uzamanın tane veriminde önemli azalışa $\left(\mathrm{r}=-0,65^{* *}\right)$ neden olduğunu göstermiştir. Diğer taraftan, tane veriminin dal sayıs1, biyolojik verim ve hasat indeksi ile arasındaki ilişkinin ise olumlu ve çok önemli (sırasıyla $\mathrm{r}=0,62^{* *}, \mathrm{r}=0,81^{* *}$ ve $\mathrm{r}=0,91^{* *}$ ) olduğu saptanmıştır (Çizelge 6). Diğer bir ifadeyle, dal sayısı, biyolojik verim ve hasat indeksinde meydana gelen artışlar tane veriminde önemli artışa neden olmuştur.

Tane verimine en fazla katk1 sağlayan parametrelerin daha ayrıntılı bir şekilde ortaya konulabilmesi için aşamalı (stepwise) çoklu regresyon analizi yapılmıştır. $\mathrm{Bu}$ analizde tane verimi bağımlı (Y), diğer 13 özellik ise bağımsız (X) değişken olarak dikkate alınmıştır. Aşamalı çoklu regresyon analizi sonuçları, 13 özellik arasında hasat indeksi $\left(\mathrm{X}_{1}\right)$ ve biyolojik verimin $\left(\mathrm{X}_{2}\right)$ en önemli verim unsurları olduğunu ortaya

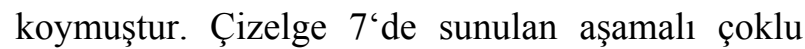
regresyon analizi sonuçları dikkate alınarak, tane veriminin tahmini için $\mathrm{Y}=-184,22+\left(6,413 \mathrm{X}_{1}+\right.$ $0,291 \mathrm{X}_{2}$ ) regresyon modeli elde edilmiştir. Bir regresyon modelinde yüksek ve önemli $\mathrm{R}^{2}$ değerinin varlığ 1 , modele giren özelliklerin tane verimi üzerindeki etkinliğinin en önemli göstergesidir (Hannachi ve ark., 2013). Aşamalı çoklu regresyon analizinden elde ettiğimiz birinci modelde hasat indeksi tane verimindeki toplam varyasyonun \%81,9'unu $\left(\mathrm{R}^{2}=0,819\right)$ temsil ederken, ikinci modelde hasat indeksi biyolojik verimle birlikte tane verimindeki toplam varyasyonun \%99,1'ini $\left(\mathrm{R}^{2}=0,991\right)$ açıklamıştır (Çizelge 7). İncelediğ parametreleri aşamalı çoklu regresyon analizine tabi tutan Habibi (2011), bulgularımıza paralel olarak, biyolojik verim, hasat indeksi ve baklada tane sayısının fasulyede tane verimindeki değişimin \%98,4'ünden sorumlu olduğunu rapor etmiştir. Diğer bazı araştırıcılar da fasulyede tane verimini belirleyen en önemli unsurların biyolojik verim ve hasat indeksi olduğunu bildirmişlerdir (Scully ve ark., 1991; Wallace ve ark., 1993; Negahi ve ark., 2014; Elkoca ve Çınar, 2015). Diğer bir çalışmada ise fasulyede tane verimi üzerindeki en etkili üç unsurun biyolojik verim, hasat indeksi ve vejetasyon süresi olduğu belirlenmiş ve bu nedenle yüksek verim için yapılacak seleksiyon çalışmalarında bu özelliklerin mutlaka dikkate alınması gerektiğine vurgu yapılmıştır (Wallace ve ark., 1993).

\section{Fasulye Genotiplerinin Cluster (Kümeleme) Analizine Göre Gruplandırılması}

Genotipler 14 kantitatif özellik bakımından cluster analizine tabi tutulmuş ve cluster analizi sonucunda genotiplerin iki ana grup altında kümelendiği saptanmıştır (Şekil 1 ve Çizelge 8). Grup-I 10 İspir fasulye hattını içerirken, Grup-II'de standart çeşitlerle birlikte 5 İspir fasulye hattı kümelenmiştir. Gruplara ait ortalama değerler incelendiğinde (Çizelge 8), her iki grubun çıkış ve çiçeklenme süresi ile çıkış yapan bitki sayısı bakımından benzer; verim ve diğer verim unsurları bakımından ise ikinci gruptaki genotiplerin daha üstün olduğu görülmektedir. Grup ortalamaları dikkate alındığında, ikinci gruptakilerin olgunlaşma süresinin bir hafta daha kısa, bitki boylarının ise yaklaşık $7 \mathrm{~cm}$ daha uzun olduğu anlaşılmaktadır (Çizelge 8). Ayrıca, ikinci grubun bitkide dal ve bakla sayısı, baklada tane sayısı ve bakla uzunluğu bakımından da daha üstün olduğu görülmektedir. $\mathrm{Bu}$ çalışmada, korelasyon ve aşamalı çoklu regresyon analizi sonuçları en önemli verim unsurlarının biyolojik verim ve hasat indeksi olduğunu (Çizelge 6 ve Çizelge 7), cluster analizi sonuçları ise bu iki parametre yönünden ikinci grubun önemli derecede üstünlük gösterdiğini ortaya koymuştur (Çizelge 8). Bu önemli iki verim unsuru bakımından gruplar arasındaki bu farklilık grupların tane verimine de yansımış ve ilk grupta ortalama $156,55 \mathrm{~kg} / \mathrm{da}$ olan tane verimi, ikinci grupta önemli bir farkla 258,94 kg/da'a yükselmiştir (Çizelge 8). 


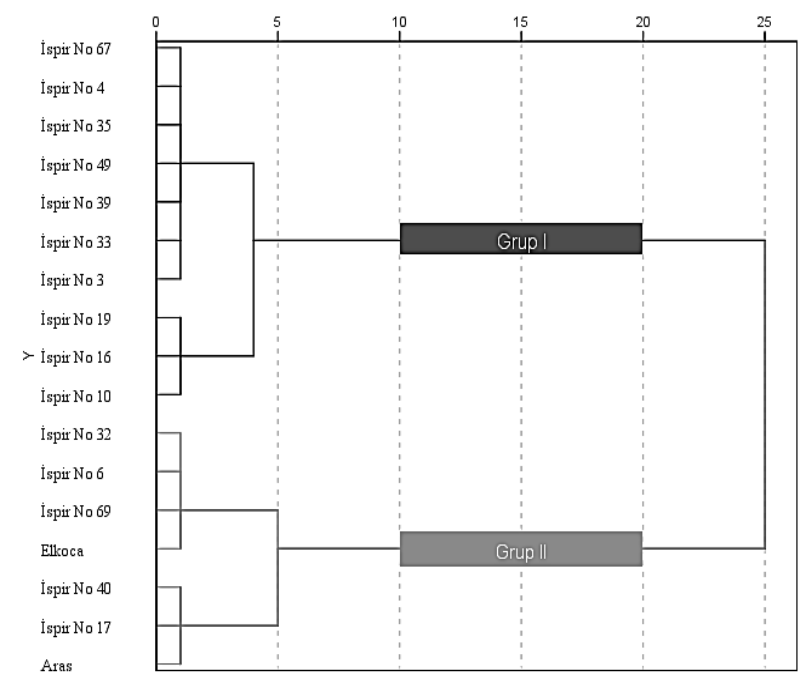

Şekil 1. Cluster analizine ait dendogram.

Figure 1. Dendogram obtained from cluster analysis.

Cluster analizinden elde ettiğimiz bu sonuçlar ümitvar hatların ikinci grupta kümelendiğini göstermiştir. Araştırmamızdan elde ettiğimiz sonuçlar ayrıca, cluster analizinin çok sayıda genotipi anlamlı bir şekilde gruplayabildiğini, dolayısıyla ileride yapılacak sslah ve çeşit geliştirme çalışmalarına aktarılacak materyallerin seçiminde bu gruplardan başarıyla yararlanılabileceğini ortaya koymuştur. Benzer şekilde, diğer araştırıcılar da genotiplerin tasnifinde cluster analizinin etkin bir şekilde kullanılabileceğine ve cluster analizinin ümitvar genotiplerin seleksiyonuna yönelik önemli ipuçları vermesi nedeniyle ıslahçılar için kullanışlı olabileceğine dair çok sayıda sonuç rapor etmişlerdir (Madakbaş ve Ergin, 2011; Kahraman ve ark., 2014; Rana ve ark., 2015).

\section{SONUÇ}

Araştırma sonuçları fenoloji, verim ve verim unsurları bakımından ispir fasulye hatları arasında seleksiyona olanak sağlayacak önemli farkların bulunduğunu göstermiştir. Cluster analizi sonuçları da bu durumu teyit etmiş ve fasulye genotipleri iki ana grup altında kümelenmiştir. Erkencilik, kısa vejetasyon süresine sahip yüksek rakımlı bölgelerde ürünün garantisi olmaktadır. Cluster analizi sonucunda oluşan gruplara ait ortalama değerler, ikinci grupta kümelenen genotiplerin (kayıt no 6, 17, 32, 40, 69, Aras-98 ve Elkoca-05) ortalama bir hafta erken olgunlaştığını, dolayısıyla ikinci grupta kümelenen genotiplerin Erzurum ve benzer ekolojiler için daha uygun olduğunu göstermiştir. Gruplara ait ortalama değerler ayrıca, bu gruptaki genotiplerin tane verimi ile birçok verim unsuru bakımından da daha üstün olduğunu ortaya koymuştur.

Yapılan gözlemlerde İspir fasulye hatlarının tamamında hiçbir bakteriyel hastalık belirtisine rastlanmamış ve bakteriyel hastalıklara toleranslı oldukları belirlenmiştir. Hatlar ayrıca virüs hastalıkları yönünden de gözden geçirilmiş ve araştırmada yer alan ispir fasulye hatlarından yalnızca 5 tanesinde (kayıt no 6,32, 33, 40 ve 69) virüs hastalığ 1 belirtisine rastlanmamıştır. Virüs hastalıklarına toleranslı olan bu beş hattan dördü (kayıt no 6, 32, 40 ve 69) yine üstün özelliklere sahip olan ikinci grupta kümelenmiştir.

Araştırmamızda cluster analizinden elde ettiğimiz bu sonuçlar cluster analizinin çok sayıda genotipi anlamlı bir şekilde gruplayabildiğini, dolayısıyla ileride yapilacak sslah ve çeşit geliştirme çalışmalarına aktarılacak materyallerin seçiminde bu gruplardan başarıyla yararlanılabileceğini göstermiştir. Diğer taraftan, gerek özellikler arasındaki doğrusal ilişkilere ait basit korelasyon katsayıları ve gerekse aşamalı (stepwise) çoklu regresyon analizinden elde edilen sonuçlar ise toplam verim ile hasat indeksinin en önemli verim unsurları olduğunu; kuru fasulyede yüksek tane verimi için yapılacak ıslah ve seleksiyon çalışmalarında bu iki özelliğin mutlaka dikkate alınması gerektiğini ortaya koymuştur.

Araştırma sonunda, başta verim ve verim unsurları ile hastalıklara tolerans olmak üzere, incelenen pek çok özellik yönünden üstün özellik gösteren 6,32 , 40 ve 69 nolu ispir fasulye hatları ile çalışmalara devam edilmesine ve bu hatların bölge verim denemelerine aktarılmasına karar verilmiştir. 


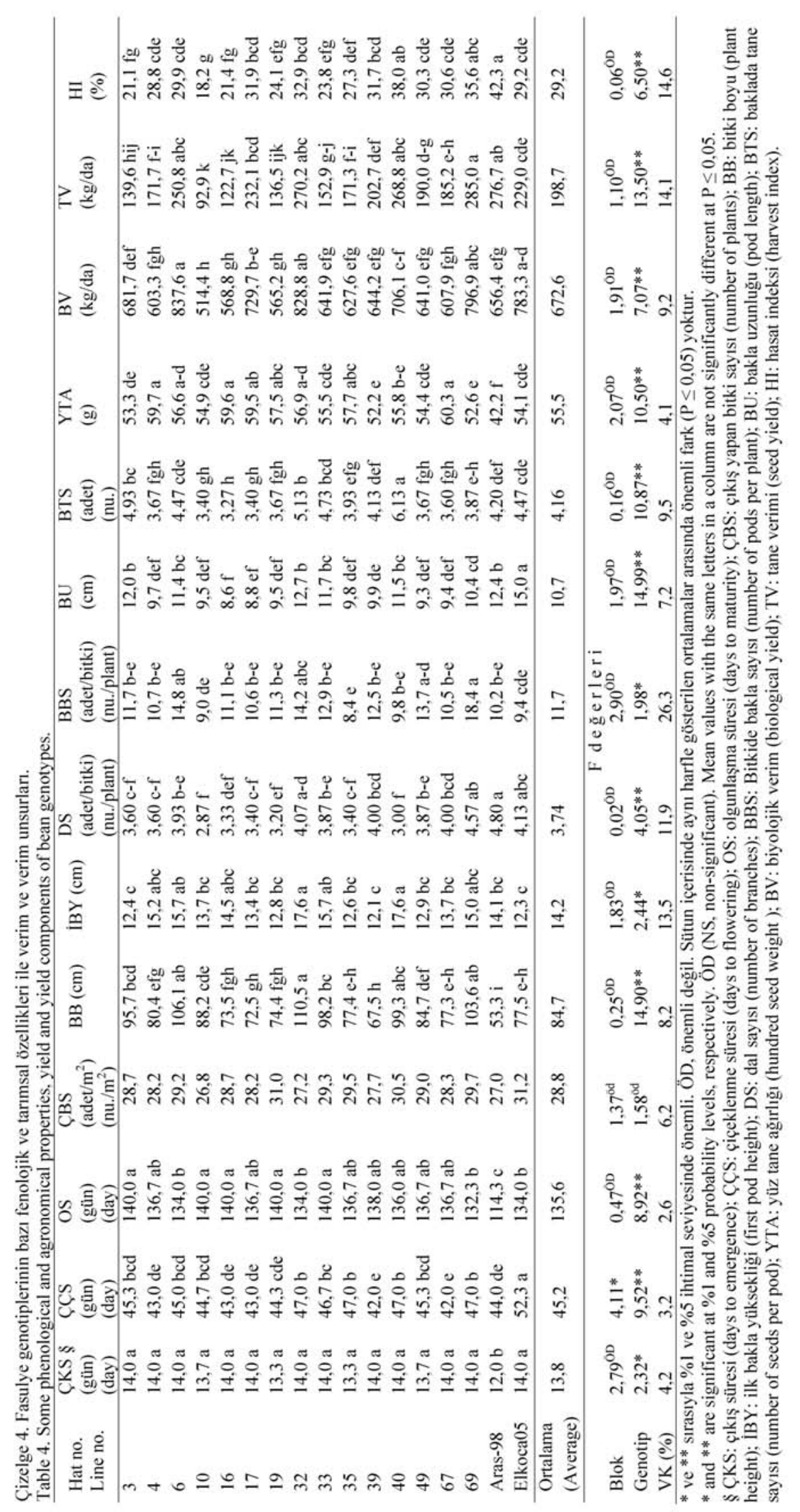


Çizelge 5. Fasulye genotiplerinin adi yaprak yanıklığı (Xanthomonas axonopodis pv. phaseoli) ve fasulye adi mozaik virüsüne reaksiyonu. Table 5. The reaction of bean genotypes to common bacterial blight (Xanthomonas axonopodis pv. phaseoli) and bean common mosaic virus.

\begin{tabular}{lcc}
\hline $\begin{array}{l}\text { Hat no. } \\
\text { Line no. }\end{array}$ & $\begin{array}{c}\text { Adi yaprak yankllı̆̆ } \S \\
\text { (Common bacterial blight) }\end{array}$ & $\begin{array}{c}\text { Fasulye adi mozaik virüsü } \psi \\
\text { (Bean common mosaic virus) }\end{array}$ \\
\hline 3 & 1 & 3 \\
4 & 1 & 4 \\
6 & 1 & 1 \\
10 & 1 & 3 \\
16 & 1 & 4 \\
17 & 1 & 5 \\
19 & 1 & 5 \\
32 & 1 & 1 \\
33 & 1 & 1 \\
35 & 1 & 3 \\
39 & 1 & 3 \\
40 & 1 & 1 \\
49 & 1 & 5 \\
69 & 1 & 5 \\
Aras-98 & 1 & 1 \\
Elkoca-05 & 4 & 1 \\
\hline
\end{tabular}

§ Donmez ve ark., 2013; $\psi$ Boersma ve ark., 2014.

Çizelge 6. Verim ve verim unsurları arasındaki ilişkileri gösteren korelasyon katsayıları.

Table 6. Correlation coefficients of the relationship between yield and yield components.

\begin{tabular}{|c|c|c|c|c|c|c|c|c|c|c|c|c|c|c|}
\hline $\begin{array}{l}\text { Özellikler } \\
\text { Traits }\end{array}$ & ÇKS§ & ÇÇS & OS & ÇBS & $\mathrm{BB}$ & BBS & $\mathrm{BU}$ & BTS & İBY & DS & YTA & TV & $\mathrm{BV}$ & $\mathrm{HI}$ \\
\hline ÇKS (DE) & 1,00 & 0,09 & $0,76^{* *}$ & 0,22 & $0,58^{*}$ & 0,28 & $-0,09$ & 0,13 & 0,20 & $-0,30$ & $0,70^{* *}$ & $-0,12$ & 0,25 & $-0,35$ \\
\hline ÇÇS (DF) & & 1,00 & $-0,07$ & $0,57^{*}$ & 0,39 & 0,03 & $0,76^{* *}$ & 0,48 & 0,11 & 0,14 & $-0,15$ & 0,29 & $0,50^{*}$ & 0,06 \\
\hline OS (DM) & & & 1,00 & 0,26 & 0,34 & $-0,04$ & $-0,40$ & $-0,11$ & $-0,12$ & $-0,70^{* *}$ & $0,76^{* *}$ & $-0,65^{* *}$ & $-0,29$ & $-0,76^{* *}$ \\
\hline ÇBS (NP) & & & & 1,00 & 0,16 & 0,02 & 0,23 & 0,24 & $-0,07$ & $-0,15$ & 0,22 & 0,06 & 0,18 & $-0,04$ \\
\hline $\mathrm{BB}(\mathrm{PH})$ & & & & & 1,00 & $0,56^{*}$ & 0,25 & $0,52^{*}$ & $0,63^{* *}$ & $-0,08$ & 0,27 & 0,19 & $0,53^{*}$ & $-0,12$ \\
\hline BBS (NPP) & & & & & & 1,00 & 0,03 & 0,07 & 0,31 & $0,51^{*}$ & $-0,11$ & 0,41 & $0,55^{*}$ & 0,22 \\
\hline BU (PL) & & & & & & & 1,00 & $0,67^{* *}$ & 0,19 & 0,45 & $-0,46$ & 0,46 & $0,60^{*}$ & 0,28 \\
\hline BTS (NSP) & & & & & & & & 1,00 & $0,55^{*}$ & 0,05 & $-0,22$ & 0,45 & $0,50^{*}$ & 0,34 \\
\hline İBY (FPH) & & & & & & & & & 1,00 & $-0,01$ & 0,13 & 0,43 & 0,38 & 0,33 \\
\hline DS (NB) & & & & & & & & & & 1,00 & $-0,59^{*}$ & $0,62^{* *}$ & $0,50^{*}$ & $0,60^{*}$ \\
\hline YTA (HSW) & & & & & & & & & & & 1,00 & $-0,37$ & $-0,12$ & $-0,47$ \\
\hline TV (SY) & & & & & & & & & & & & 1,00 & $0,81^{* *}$ & $0,91^{* *}$ \\
\hline BV (BY) & & & & & & & & & & & & & 1,00 & $0,51^{*}$ \\
\hline HI & & & & & & & & & & & & & & 1,00 \\
\hline
\end{tabular}

* ve ** sirasıyla \%1 ve \%5 ihtimal seviyesinde önemli; * and ** are significant at $\% 1$ and $\% 5$ probability levels, respectively. § ÇKS: çıkış süresi (DE: days to emergence); ÇÇS: çiçeklenme süresi (DF: days to flowering); OS: olgunlaşma süresi (DM: days to maturity); ÇBS: Çıkış yapan bitki sayısı (NP: number of plants); BB: Bitki boyu (PH: plant height); BBS: Bitkide bakla sayısı (NPP: number of pods per plant); BU: bakla uzunluğu (PL: pod length); BTS: Baklada tane sayısı (NSP: number of seeds per pod); İBY: ilk bakla yüksekliği (FPH: first pod height); DS: dal sayısı (NB: number of branches); YTA: yüz tane ağırlığı (HSW: hundred seed weight); TV: tane verimi (SY; seed yield); BV: biyolojik verim (BY: biological yield); HI: hasat indeksi (harvest index).

Çizelge 7. Tane verimi için aşamalı (stepwise) çoklu regresyon analizi.

Table 7. Stepwise multiple regression analysis for grain yield.

\begin{tabular}{clcccc}
\hline $\begin{array}{l}\text { Model numaras1 } \\
\text { Model number }\end{array}$ & $\begin{array}{l}\text { Modele giren özellik } \\
\text { Model parameters }\end{array}$ & $\begin{array}{c}\text { Regresyon sabiti } \\
\text { Regression constant }\end{array}$ & $\begin{array}{c}\text { Regresyon katsayis1 } \\
\text { Regression coefficient }\end{array}$ & $\mathrm{R}^{2}$ & $\mathrm{~F}$ \\
\hline 1 & $\begin{array}{l}\text { Hasat indeksi } \\
\text { (Harvest index) }\end{array}$ & $-54,214$ & 8,652 & 0,819 & $73,64^{* *}$ \\
& $\begin{array}{l}\text { Hasat indeksi } \\
\text { (Harvest index) } \\
\text { Biyolojik verim } \\
\text { (Biological yield) }\end{array}$ & $-184,22$ & 6,413 & & \\
& & & 0,291 & 0,991 & $879,883^{* *}$ \\
\hline
\end{tabular}


Çizelge 8. Cluster analizinde oluşan gruplar ve grupların incelenen özelliklere ait ortalamaları.

Table 8. Groups formed in cluster analysis and averages of groups in terms of the features studied.

\begin{tabular}{lrr} 
& \multicolumn{1}{c}{ Grup-I } & Grup-II \\
Özellikler & Hat no (Line nu.) & Hat no (Line nu.) \\
Traits & $3,4,10,16,19$, & $6,17,32,40,69$, \\
& $33,35,39,49,67$ & Aras-98, Elkoca-05 \\
\cline { 2 - 3 } Çıkış süresi (gün) (Days to emergence) & $13,80 \pm 0,28$ & $13,71 \pm 0,76$ \\
Çiçeklenme süresi (gün) (Days to flowering) & $44,33 \pm 1,80$ & $46,48 \pm 3,04$ \\
Olgunlaşma süresi (gün) (Days to maturity) & $138,47 \pm 1,66$ & $131,62 \pm 7,76$ \\
Çıkış yapan bitki sayısı (adet/m²) (Number of plants) & $28,72 \pm 1,13$ & $28,98 \pm 1,61$ \\
Bitki boyu (cm) (Plant height) & $81,73 \pm 9,89$ & $88,99 \pm 21,42$ \\
Bitkide bakla sayisı (adet) (Number of pods per plant) & $11,18 \pm 1,66$ & $12,50 \pm 3,38$ \\
Baklada tane sayısı (adet) (Number of seeds per pod) & $3,90 \pm 0,55$ & $4,52 \pm 0,89$ \\
Bakla uzunluğu (cm) (Pod length) & $9,94 \pm 1,07$ & $11,76 \pm 1,95$ \\
İlk bakla yüksekliği (cm) (First pod height) & $13,58 \pm 1,23$ & $15,10 \pm 2,02$ \\
Dal sayısı (adet/bitki) (Number of branches) & $3,57 \pm 0,37$ & $3,99 \pm 0,63$ \\
Tane verimi (kg/da) (Seed yield) & $156,55 \pm 34,03$ & $258,94 \pm 22,00$ \\
Biyolojik verim (kg/da) (Biological yield) & $609,59 \pm 48,86$ & $762,69 \pm 67,28$ \\
Hasat indeksi (\%) (Harvest index) & $25,73 \pm 4,69$ & $34,24 \pm 4,69$ \\
Yüz tane ağırlığ1 (g) (Hundred seed weight) & $56,51 \pm 2,86$ & $53,96 \pm 5,63$ \\
\hline
\end{tabular}

\section{TEŞEKKÜR}

$\mathrm{Bu}$ çalışma, Atatürk Üniversitesi Fen Bilimleri Enstitüsü'nde yürütülen "İleri İspir Kuru Fasulye (Phaseolus vulgaris L.) Hatlarında Verim ve Kalite
Çalışmaları" başlıklı yüksek lisans tezinin bir k1smını kapsamakta olup, yazarlar desteklerinden dolayı TÜBİTAK'a (Proje no 115O260) teşekkür etmektedir.

\section{LITERATÜR LISTESI}

Akdağ, C. ve M. Şahin. 1994. Tokat şartlarına uygun kuru fasulye çeşitlerinin belirlenmesi üzerine bir araştırma. Gaziosmanpaşa Üniversitesi Ziraat Fakültesi Dergisi 11 (1): $101-111$

Anlarsal, A. E., C. Yücel ve D. Özveren. 2000. Cukurova koşullarında bazı fasulye (Phaseolus vulgaris L.) çeşitlerinde tane verimi ve verimle ilgili özellikler ile bu özellikler arası ilişkilerin saptanması. Turkish Journal of Agriculture and Forestry 24: 19-29.

Anonim. 2001. Tarımsal Değerleri Ölçme Denemeleri Teknik Talimatı. Yemeklik Tane Baklagiller. T.C. Tarım ve Köyişleri Bakanlığı, Koruma ve Kontrol Genel Müdürlüğü, Tohumluk Tescil ve Sertifikasyon Merkezi Müdürlüğü, Ankara.

Anonim. 2015. Y1llık iklim rasatları. Meteoroloji Bölge Müdürlüğü, Erzurum.

Anonim. 2018. Food and Agriculture Organization of the United Nations (FAOSTAT) http://www.fao.org/ faostat/en/\#data/QC. (Erișim tarihi 14/05/2020).

Anonymous. 2011. IBM SPSS Statistics Base 20. IBM Corp. Armonk, NY, USA.
Aydın, A. ve Y. Sezen. 1995. Toprak kimyası laboratuvar kitabı. Atatürk Üniversitesi Ziraat Fakültesi Ders Yayınları No: 174, Erzurum.

Balkaya, A. 1999. Karadeniz bölgesindeki taze fasulye (Phaseolus vulgaris L.) gen kaynaklarının toplanmas1, fenolojik ve morfolojik özelliklerinin belirlenmesi ve taze tüketime uygun tiplerin teksel seleksiyon yöntemi ile seçimi üzerinde araştırmalar. Doktora tezi. Ondokuz Mayıs Üniversitesi Fen Bilimleri Enstitüsü, Samsun.

Bıyıkl1, B. 2015. İspir kuru fasulye (Phaseolus vulgaris L.) populasyonunun karakterizasayonu ve seleksiyon yoluyla 1slahı. Yüksek lisans tezi. Atatürk Üniversitesi Fen Bilimleri Enstitüsü Erzurum.

Boersma, J. G., R. L. Conner, P. M. Balasubramanian, A. Navabi, K. Yu, and A. Hou. 2014. Combining resistance to common bacterial blight, anthracnose, and bean common mosaic virus into Manitoba-adapted dry bean (Phaseolus vulgaris L.) cultivars. Canadian Journal of Plant Science 94: 405-415.

Bozoğlu, H. 1995. Kuru fasulyede (Phaseolus vulgaris L.) bazı tarımsal özelliklerin genotip $\mathrm{x}$ çevre interaksiyonu ve kalıtım derecelerinin belirlenmesi üzerine bir araștırma. Doktora tezi. Ondokuz Mayıs Üniversitesi Fen Bilimleri Enstitüsü, Samsun. 
Bozoğlu, H. ve Ö. Sözen. 2007. Some agronomic properties of the local population of common bean (Phaseolus vulgaris L.) of Artvin province. Turkish Journal of Agriculture and Forestry 31: 327-334.

Ceyhan, E., M. Önder ve A. Kahraman. 2009. Fasulye genotiplerinin bazı tarımsal özelliklerinin belirlenmesi. Selçuk Üniversitesi Selçuk Tarım ve Gıda Bilimleri Dergisi 23 (49): 67-73.

Çiftçi, C. Y. ve S. Şehirali. 1984. Fasulye (Phaseolus vulgaris L.) çeşitlerinde değişik özelliklerin fenotipik ve genotipik farklılıkların saptanması. Ankara Üniversitesi Fen Bilimleri Enstitüsü Yayın No: TB 4. Ankara.

Donmez, M. F., F. Sahin, and E. Elkoca. 2013. Identification of bean genotypes from Turkey resistance to common bacterial blight and halo blight diseases. Acta Scientiarum Polonorum, Hortorum Cultus 12 (4): 139-151.

Dönmez, M. F. 2004. Erzurum-Erzincan illerinde fasulye bitkisinde (Phaseolus vulgaris L.) görülen bakteriyel hastalıkların tanımlanması ve Pseudomonas syringae pv. phaseolicola ve Xanthomonas campestris pv. phaseoli'ye karşı çeşitli fasulye genotip/varyetelerinin duyarlılıklarının belirlenmesi. Doktora tezi. Atatürk Üniversitesi Fen Bilimleri Enstitüsü Erzurum.

Dumlu, B. 2009. Kuzey Doğu Anadolu Bölgesinden toplanılan 23 fasulye (Phaseolus vulgaris L.) genotipinin fenolojik ve morfolojik karakterizasyonu. Yüksek lisans tezi. Atatürk Üniversitesi Fen Bilimleri Enstitüsü Erzurum.

Düzdemir, O. ve C. Akdağ. 2001. Türkiye kuru fasulye (Phaseolus vulguris L.) gen kaynaklarının karakterizasyonu. II: Verim ve diğer bazı özellikler. Gaziosmanpaşa Üniversitesi Ziraat Fakültesi Dergisi 18 (1): 101-105.

Elkoca, E. ve F. Kantar. 2004. Erzurum ekolojik koşullarına uygun erkenci ve yüksek verimli kuru fasulye (Phaseolus vulgaris L.) genotiplerinin belirlenmesi. Atatürk Üniversitesi Ziraat Fakültesi Dergisi 35 (3-4): 137142.

Elkoca, E. ve T. Çınar. 2015. Bazı kuru fasulye (Phaseolus ulgaris L.) çeşit ve hatlarının Erzurum ekolojik koşullarına adaptasyonu, tarımsal ve kalite özellikleri. Anadolu Tarım Bilimleri Dergisi 30: 141-153.

Freed, R., S. P. Eisensmith, S. Goetz, D. Reicosky, V. W. Smail, and P. Wolberg. 1985. MSTAT ver 4.0: a microcomputer program for design, management and analysis of agronomic research experiments. Michigan State University, USA.

Güneş, Z. 2011. Van-Gevaş'da ümitvar bulunan fasulye (Phaseolus vulgaris L.) hatlarında verim ve bazı verim öğelerinin belirlenmesi. Yüksek lisans tezi. Yüzüncü Y1l Üniversitesi Fen Bilimleri Enstitüsü Van.

Habibi, G. 2011. Influence of drought on yield and yield components in white bean. International Journal of Biological, Biomolecular, Agricultural, Food and Biotechnological Engineering 5 (7): 380-389.
Hannachi, A., Z. E. Fellahi, H. Bouzerzour, and A. Boutekrabt. 2013. Correlation, path analysis and stepwise regression in durum wheat (Triticum durum Desf.) under rainfed conditions. Journal of Agriculture and Sustainability 3 (2): 122-131.

Kahraman, A., M. Önder, and E. Ceyhan. 2014. Cluster analysis in common bean genotypes (Phaseolus vulgaris L.). Turkish Journal of Agricultural and Natural Sciences, Special Issue 1: 1030-1035.

Kahveci, E., and S. Maden. 1994. Detection of Xanthomonas campestris pv. phaseoli and Pseudomonas syringae pv. phaseolicola by bacteriophages. Journal of Turkish Phytopathology 23: 79-85.

Kantar, F. ve E. Elkoca. 2001. Bazı fasulye (Phaseolus vulgaris L.) çeşitlerinin kardinal ve toplam sıcaklık isteklerinin belirlenmesi. Türkiye 4. Tarla Bitkileri Kongresi. 17-21 Eylül 2001. Cilt I Tahıllar ve Yemeklik Tane Baklagiller. Tekirdağ. s. 371-375.

Kılıç, H. Ç., H. Kök, and N. Yardımcı. 2020. Bean common mosaic virus and bean common mosaic necrosis virus infections in bean production areas in The Lakes Region of Turkey. European Journal of Science and Technology 19: 386-392.

Madakbaş, S. Y., and M. Ergin. 2011. Morphological and phenological characterization of Turkish bean (Phaseolus vulgaris L.) genotypes and their present variation states. African Journal of Agricultural Research 6 (28): 6155-6166.

Mavric, I., and J. Sustar-Vozlic. 2004. Virus diseases and resistance to bean common mosaic and bean common mosaic necrosis potyvirus in common bean (Phaseolus vulgaris L.). Acta Agriculturae Slovenica 83 (1): 181-190.

Negahi, A., M. R. Bihamta, Z. Negahi, and M. Alidoust. 2014. Evaluation of genetic variation of some agronomical and morphological traits in Iranian and exotic common bean (Phaseolus vulgaris L.). Agricultural Communications 2 (3): 22-26.

Ozturk, I., M. Kara, C. Yildiz, and S. Ercisli. 2009. Physicomechanical seed properties of the common Turkish bean (Phaseolus vulgaris) cultivars 'Hınıs' and 'Ispir'. New Zealand Journal of Crop and Horticultural Science 37: 41-50.

Özbekmez, Y. 2015. Ordu ekolojik koşullarında bazı kuru fasulye (Phaseolus vulgaris L.) çeşit ve genotiplerinin verim, verim öğeleri ile tohum ve teknolojik özelliklerinin belirlenmesi. Yüksek lisans tezi. Ordu Üniversitesi Fen Bilimleri Enstitüsü Ordu.

Özçelik, H. ve A. Gülümser. 1988. Bazı bodur fasulye ( $P$. vulgaris L.) çeşitlerinde verim ve bazı verim öğeleri üzerine bir araştırma. Ondokuz Mayıs Üniversitesi Ziraat Fakültesi Dergisi 3 (1): 99-108.

Pekşen, E. ve A. Gülümser. 2005. Bazı fasulye (Phaseolus vulgaris L.) genotiplerinde verim ve verim unsurları arasındaki ilişkiler ve path analizi. Ondokuz Mayıs Üniversitesi Ziraat Fakültesi Dergisi 20 (3): 82-87. 
Pekşen, E. ve C. Artık. 2005. Antibesinsel maddeler ve yemeklik tane baklagillerin besleyici değerleri. Anadolu Tarım Bilimleri Dergisi 20 (2): 110-120.

Rana, J. C., T. R. Sharma, R. K. Tyagi, R. K. Chahota, N. K. Gautam, M. Singh, P. N. Sharma, and S. N. Ojha. 2015. Characterisation of 4274 accessions of common bean (Phaseolus vulgaris L.) germplasm conserved in the Indian gene bank for phenological, morphological and agricultural traits. Euphytica 205: 441-457.

Sakiroglu, H., E. Yılmaz, M. Erat, and A. E. Öztürk. 2013 Selected properties of polyphenol oxidase obtained from İspir sugar bean. International Journal of Food Properties 16: 1314-1321.

Scully, B. T., D. H. Vallace, and D. R. Vands. 1991 Heritability and correlation of biomass, growth rates, harvest index, and phenology to the yield of common beans. Journal of the American Society for Horticultural Science 116: 127-130.

Sever, R. 2005. Coğrafi Açıdan Bir Araştırma: Çoruh Havzası Enerji Yatırım Projeleri ve Çevresel Etkileri. Çizgi Kitabevi Yayınları No: 118, Kaynak Kitaplar No: 9. Konya.

Sözen, Ö. 2006. Artvin ili yerel fasulye (Phaseolus vulgaris L.) populasyonlarının toplanması, tanımlanması ve morfolojik varyabilitesinin belirlenmesi. Yüksek lisans tezi. Ondokuz Mayıs Üniversitesi Fen Bilimleri Enstitüsü Samsun.

Topcu, Y., A. S. Uzundumlu, and F. Yavuz. 2010. Designing the marketing strategies for Ispir sugar bean as a local product using conjoint analysis. Scientific Research and Essays 5 (9): 887-896.
Ustaoğlu, Y. N. 2008. Tescilli kuru fasulye (Phaseolus vulgaris L.) çeşitlerinde çeşitli fenolojik dönemler için toplam sicaklık isteklerinin belirlenmesi. Yüksek lisans tezi. Atatürk Üniversitesi, Fen Bilimleri Enstitüsü, Erzurum.

Varankaya, S. 2011. Yozgat ekolojik şartlarında yetiştirilen fasulye (Phaseolus vulgaris L.) genotiplerinin bazı tarımsal özelliklerinin belirlenmesi. Yüksek lisans tezi. Selçuk Üniversitesi Fen Bilimleri Enstitüsü, Konya.

Wagenvoort, W. A., and J. F. Bierhuizen. 1977. Some aspects of seed germination in vegetables. II. The effect of temperature fluctuation, depth of sowing, seed size and cultivar, on heat sum and minimum temperature for germination. Scientia Horticulturae 6 (4): 259-270.

Wallace, D. H., J. P. Baudoin, J. S. Beaver, D. P. Coyne, D. E. Halseth, P. N. Masaya, H. M. Munger, J. R. Myers, M. Silbernagel, K. S. Yourstone, and R. W. Zobel. 1993. Improving efficiency of breeding for higher crop yield. Theoretical and Applied Genetics 86 (1): 27-40.

Ward, J. H. 1963. Hierarchical grouping to optimize an objective function. Journal of the American Statistical Association 58: 236-244.

Yıldız, N. ve H. Bircan. 1991. Araştırma ve Deneme Metotları. Atatürk Üniversitesi Yayın No: 697, Ziraat Fakültesi Yayın No: 305, Ders Kitapları Serisi No: 57, Erzurum.

Zirek, İ. 2015. Türkiye'de tescil edilmiş bazı fasulye (Phaseolus vulgaris L.) çeşitlerinin verim ve bazı verim özelliklerinin belirlenmesi, Yüksek lisans tezi. Yüzüncü Y1l Üniversitesi Fen Bilimleri Enstitüsü Van. 